\title{
Cut antenna, a new sex-limited mutant of Aedes togoi
}

\author{
Takeo TADANO* \\ Department of Medical Zoology, St. Marianna University School of Medicine, \\ Sugao, Kawasaki City, Kanagawa Prefecture 213, Japan
}

(Received: March 30, 1978)

\begin{abstract}
A new recessive, sex-limited mutant, cut antenna ( $c a)$, of the mosquito Aedes (Finlaya) togoi (Theobald) was located in the order of $p$ (pigmented pupa)-ru (ruby eye) $-c a$ in linkage group 2. The recombination values between $p$ and $r u$, and between $r u$ and $c a$ were $27.06 \pm 1.70$ to $31.31 \pm 1.96 \%$ and $6.98 \pm 1.08$ to $11.77 \pm 1.24 \%$, respectively. 4 to 7 antennal segments are lost in $c a$ females but the ca allele does not affect male antennae; the allele appears to exhibit complete penetrance with some variation in its expressivity.
\end{abstract}

Basic genetics of the mosquito Aedes (Fin. laya) togoi (Theobald), a natural or experimental vector of filariae, has been studied in our laboratory to accumulate the materials needed for comparative genetic studies among the Aedes mosquitoes and for genetic analysis of problems of medical importance. Eight genetic markers have been placed in all three linkage groups of this mosquito, its haploid chromosome number being three (Tadano, 1977a, 1978), but further work of this series should be continued for establish. ment of precise linkage groups in this species.

The inheritance of a new recessive mutant, cut antenna, was investigated using representative markers of the three linkage groups. This paper presents results of the crosses involving cut antenna.

\section{MATERIALS AND METHODS}

Several female pupae of cut antenna ( $c a$ ) were detected during microscopic work on single families of the Miura strain in July, 1975. No males of this trait have been found in all generations of this colony; therefore, each generation was maintained

*只野長夫：聖マリアンナ医科大学病害動物学教室 （元213 川崎市高津区营生2095） by putting $\mathrm{ca}$ females together with their wild-type brothers into the cage. For this reason only $c a$ females were utilized for all crosses performed in the present study.

The Miura and Manazuru strains were employed as wild-type strains for production of heterozygotes for the mutant alleles used here. The Miura and Manazuru strains were collected in rock pools on the seashores at Miura City and Manazuru, Kanagawa Prefecture, respectively.

The methods for rearing and crossing mosquitoes were same as those previously reported (Tadano, 1976, 1977b). Mass crosses were made in all experiments, but single blooded females were isolated in separate plastic cups and each egg batch laid by single females was hatched in a plastic box containing salted tap water (about $2 \%$ ); the hatched larvae were reared separately as a family.

After classification of offspring phenotypes was performed in each family, chi ${ }^{2}$-tests were made to examine whether observed phenotype ratios in each family fit the expected ratios. Only families in which all the observed ratios did not differ significantly $(P>0.05$, with one degree of freedom) from the expected were pooled for subsequent statistical treatment, from which all other 


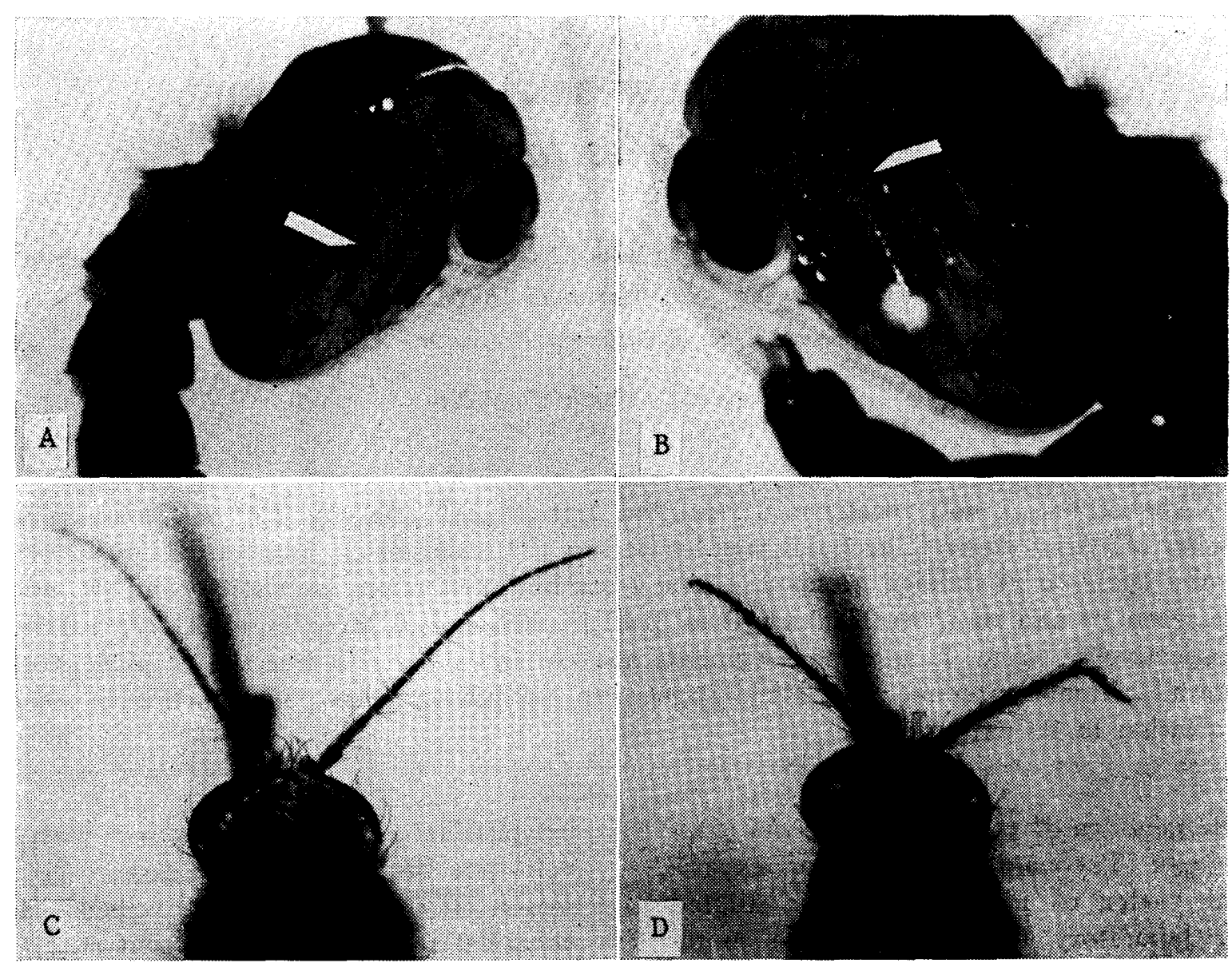

Fig. 1 The cut antenna and wild-type antenna in pupal and adult stages (A, C: wild type, B, D : cut antenna)

Arrows indicate tips of antennae.

families were discarded.

\section{RESULTS AND DISCUSSION}

A normal antenna is composed of 13 segments, while 4 to 7 segments of these are lost in $c a$ females and so the antennae are about a half as long as normal. The ca trait can be distinguished in pupae from the wild type; as seen in a $c a$ pupa (Fig. 1), remaining segments of the antenna become slightly thickened and sometimes bent. The $c a$ allele appears to exhibit complete penetrance, although some variation in its expresssion was noted and a few $c a$ individuals are likely to experience difficulty in emergence.

Six crosses, of which three were $F_{1} \times F_{1}$ crosses and the other three were testcrosses, were made to find out which linkage group the $\mathrm{ca}$ belongs to. Scores from all the crosses are given in Table 1 ; here the alleles above lines in heterozygous parental genotypes are of maternal origin and the alleles below the lines were derived from males. The $s$ (straw-colored larva) is a linkage group 1 marker; the $r u$ (ruby eye) and $p$ (pigmented pupa) alles are in linkage group 2 , while the $y$ (yellow larva) belongs to the group 3 (Tadano, 1977b, c).

Testcrosses (D, E, and F) produced no single $\mathrm{ca}$ male, which indicates sex-limited inheritance of the $c a$ allele. From data in each cross (A through $\mathrm{F}$ ), linkage relationships among the alleles involved were tested by $\mathrm{chi}^{2}$, following the formula described by Bailey (1961). The $\mathrm{chi}^{2}$ values among $c a, r u, p, s$, and $y$ are shown in Table 2; the values between $c a$ and $r u$, between $c a$ and $p$, and between $r u$ and $p$ are significant at $1 \%$ level, although the two values (4.46 and 2.10) for ca-ru (cross C) and ca-p (cross B) are exceptionally low. This fact strongly suggests existence of linkage among the al- 


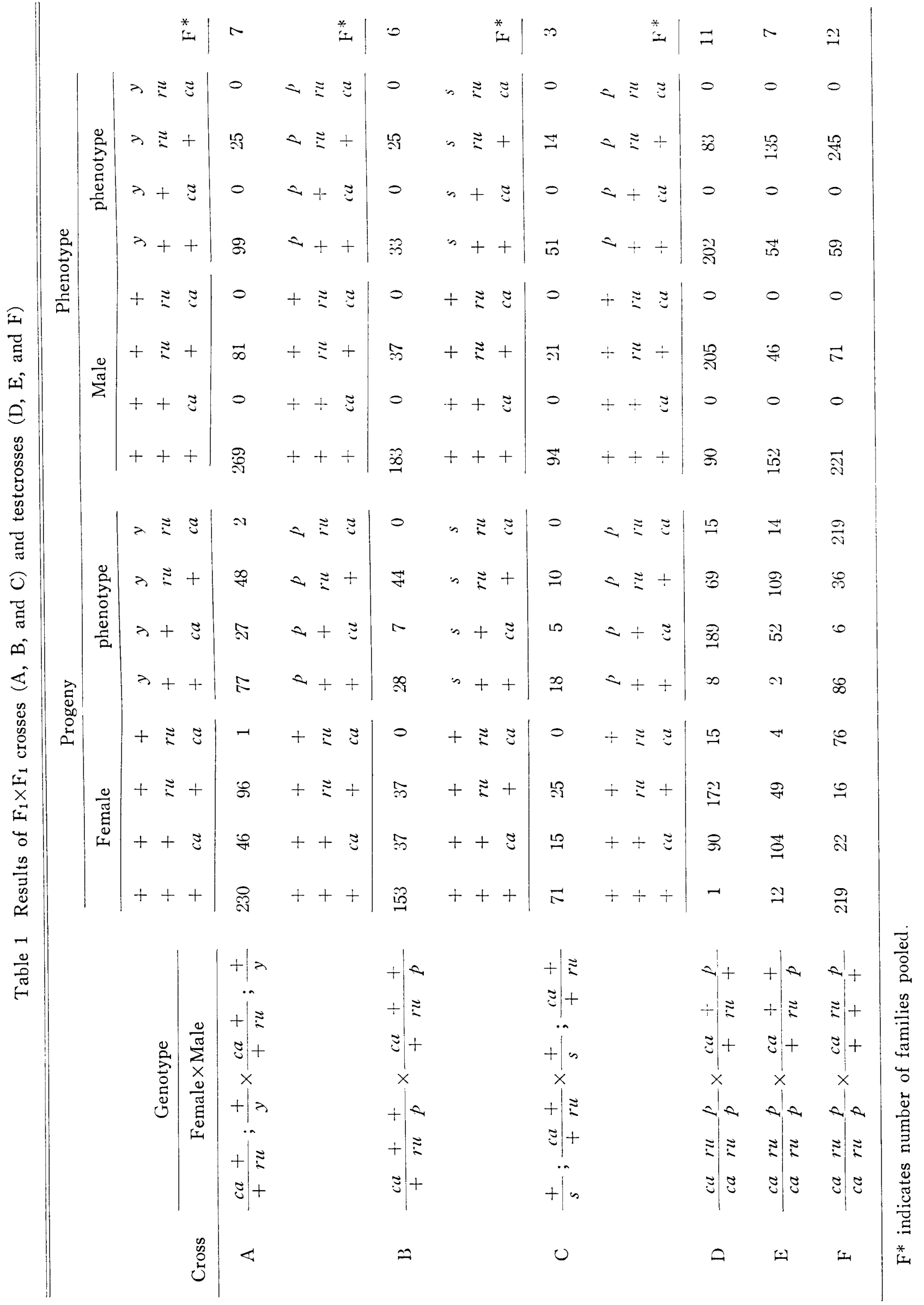


Table $2 \mathrm{Chi}^{2}$ linkage tests for $\mathrm{F}_{1} \times \mathrm{F}_{1}$ crosses and testcrosses with one degree of freedom

\begin{tabular}{|c|c|c|c|c|c|c|c|}
\hline Cross & $c a-r u$ & $c a-p$ & $r u-p$ & ca-s & $c a-y$ & $r u-y$ & $r u-s$ \\
\hline$\underset{\left(F_{1} \times F_{1}\right)}{A}$ & $21.19^{*}$ & & & & 1.06 & 3.19 & \\
\hline$\stackrel{\mathrm{B}}{\left(\mathrm{F}_{1} \times \mathrm{F}_{1}\right)}$ & $13.67^{*}$ & 2.10 & $61.38 *$ & & & & \\
\hline$\underset{\left(F_{1} \times F_{1}\right)}{\mathrm{C}}$ & $4.46^{* *}$ & & & 0.11 & & & 0.44 \\
\hline$\underset{\text { (testcross) }}{\mathrm{D}}$ & $413.88^{*}$ & $68.02^{*}$ & $78.14^{*}$ & & & & \\
\hline$\underset{\text { (testcross) }}{E}$ & $229.84^{*}$ & $24.46^{*}$ & $50.36^{*}$ & & & & \\
\hline$\underset{\text { (testcross) }}{\mathrm{F}}$ & $397.65^{*}$ & $84.71^{*}$ & $143.15^{*}$ & & & & \\
\hline
\end{tabular}

* Significant $(P \ll 0.01)$

$* * 0.05>P>0.02$

Table 3 Percent recombinations and $( \pm)$ standard errors obtained from testcrosses

\begin{tabular}{crcc}
\hline Cross & \multicolumn{1}{c}{$c a-r u$} & ru-p & $c a-p$ \\
\hline D & $6.98 \pm 1.08$ & $31.31 \pm 1.96$ & $32.56 \pm 1.98$ \\
E & $9.25 \pm 1.55$ & $30.93 \pm 2.48$ & $36.71 \pm 2.59$ \\
F & $11.77 \pm 1.24$ & $27.06 \pm 1.70$ & $32.35 \pm 1.79$ \\
\hline
\end{tabular}

leles, $c a, r u$, and $p$. and that the other alleles, $s$ and $y$, are inherited independently of each other, as previously reported (Tadano, $1977 b, c)$.

Therefore, percent recombinations among the three alleles, $c a, r u$, and $p$ were estimated and are given in Table 3 , in which only the recombination values resulted from testcrosses are tabulated since linkage data from testcrosses are more reliable than those from $F_{1} \times F_{1}$ crosses. All three sets of recombination values calculated from results of crosses, $D, E$, and $F$ give good evidence that the alleles are located in the order of $c a-$ $r u-p$; the recombination value for the $c a$ -ru segment varied from $6.98 \pm 1.08$ to $11.77 \pm 1.24 \%$, and the recombination distance between $r u$ and $p$ was very much greater ranging between $27.06 \pm 1.70$ and $31.31 \pm 1.96 \%$, which agree closely with the values obtained in previous studies.

\section{ACKNOWLEDGMENTS}

The author thanks Mrs. S. Sugiyama of this laboratory for rearing the mosquito larvae. This investigation received financial support from the World Health Organization.

\section{REFERENCES}

Bailey, N. T. J. (1961): Introduction to the mathematical theory of genetic linkage, $294 \mathrm{pp}$., Oxford Press, London.

Tadano, T. (1976): A new sex-linked mutant, reddish eye, of the mosquito Aedes togoi. Jap. J. Sanit. Zool., $27: 247-249$.

Tadano, T. (1977a): Inheritance of a new mutant, plum eye, in the mosquito Aedes togoi. Mosq. News, $37:$ 440-443.

Tadano, T. (1977b): Genetics of three new mutants, straw-colored larva, ruby eye and pigmented pupa, in Aedes (Finlaya) togoi (Diptera: Culicidae). J. Med. Entomol., 14: 33-37.

Tadano, T. (1977c): The inheritance of a mutant yellow larva in the mosquito Aedes togoi. Ann. Trop. Med. Parasitol., 71:361365.

Tadano, T. (1978): Genetics of a new mutant, curved wing, of the mosquito Aedes togoi. Ann. Trop. Med. Parasitol., in press.

\section{摘 要 \\ トウゴウヤブカの限性突然 \\ 変異体 cut antenna}

この蚊の遺伝子連鎖群の研究の一部として, cut antenna (ca) の遺伝様式を調べた. この変異は雌の触 角にのみ現われるもので, 雄の触角には現われない.す なわち，野生型の雌の触角注13節からできているが，こ の変異体では 4 ないし 7 節欠失している. この遺伝子は 第 2 連鎖群に属し, $c a-(7 \sim 12 \%)-r u$ (ruby eye)$(27 \sim 31 \%)-p$ (pigmented pupa) の順序に並んでい る. 表現度に少々の変異はあるが，浸透度は完全である と思われる。 